\title{
A High Level of Knowledge Increases The Positive Attitude of Nurses Regarding Covid-19
}

\author{
Tri Gunarti1, Budi Hartoyo1, Heru Noor Ramadhan1, Wahyuni Ika Putranti', Amin \\ Husni $^{2}$, Retnaningsih Retnaningsih ${ }^{2}$
}

1 Instalasi Rawat Intensif, RSUP Dr. Kariadi

2 Bagian Neurologi, RSUP Dr. Kariadi

\section{Article Info}

\section{Article History:}

Submitted: April $4^{\text {th }}, 2021$

Accepted: May 27th 2021

Published: May 31 ${ }^{\text {st }}, 2021$

Keywords:

Attitudes; Coronavirus;

Knowledge; Nurse

\begin{abstract}
During the Covid-19 patients' treatment process in the hospital, nurses play an important role in preventing the Covid-19 outbreak through proper care and prevention procedures because nurses are in direct contact with Covid19 patients. This study aimed to produce an analysis of nurses' level of knowledge and attitudes regarding Covid-19 in the Covid-19 isolation ward of Dr Kariadi Hospital Semarang. This is a descriptive correlation study with a cross-sectional design. The study was conducted on 81 nurses who had or are currently taking care of Covid-19 patients in the isolation ward of $\mathrm{Dr}$ Kariadi Hospital Semarang by consecutive sampling. The data were analyzed by the Spearman Rho test. The results of the study showed that 81 nurses $(100 \%)$ had a high level of knowledge regarding Covid-19 and had good attitudes towards Covid-19 prevention. The result showed a strong relationship between the level of knowledge and attitudes regarding Covid19 with a positive correlation $(\mathrm{r}=0.617)$. The study result concluded that the higher the level of knowledge, the better the attitude of nurses regarding Covid-19.
\end{abstract}

\section{PENDAHULUAN}

Dunia mendapatkan musibah dengan merebaknya virus baru yaitu coronavirus jenis baru (SARS-CoV-2) dan penyakitnya disebut Coronavirus Disease 2019 (Covid19) pada awal tahun 2020. Diketahui, asal mula virus ini berasal dari Wuhan, Tiongkok pada akhir desember 2019[1]. Virus ini sangat menular dan memberikan dampak buruk bagi penderita. Pasien harus di rawat di ruang isolasi dan mendapatkan pemantauan khusus. Petugas kesehatan juga harus selalu menggunakan proteksi diri yang ketat saat merawat pasien. Mereka sangat rentan untuk tertular penyakit. Keadaan ini akan menjadi salah satu sumber stress bagi petugas kesehatan. Stres bertambah dengan kondisi yang harus lama terpisah dengan keluarga karena merawat pasien di ruang isolasi. Kondisi ini tentu akan meningkatkan stress pada petugas kesehatan. Perawat sebagai salah satu petugas kesehatan di ruang rawat isolasi tentunya harus memiliki pemahaman dan sikap yang baik terkait pengelolaan pasien

\footnotetext{
Corresponding author:

Tri Gunarti

trigunarti1007@gmail.com

Media Keperawatan Indonesia, Vol 4 No 2, May 2021

e-ISSN: 2615-1669

ISSN: 2722-2802

DOI: $10.26714 / \mathrm{mki} .4 .2 .2021 .114-119$
} 
Covid 19. Pengetahuan dan sikap yang baik ini juga dapat berkaitan dengan pola piker dan pengendalian stress oleh perawat.

Penelitian lain menunjukkan bahwa petugas kesehatan memiliki tingkat pengetahuan dan sikap yang rendah dalam penanganan Mers-Cov serta penyakit infeksi lainnya[2]. Penelitian lain juga menunjukkan adanya tingkat pengetahuan dan sikap yang rendah mengenai MersCov[3]. Hasil tersebut didukung kembali oleh penelitian yang menyebutkan perawat memiliki pengetahuan yang rendah tentang caring kepada pasien dengan Covid-19 dimana hal ini tercermin dari sikapnya[4]. Perhatian lebih harus diberikan kepada pengetahuan dan sikap perawat yang bekerja di rumah sakit yang merawat pasien Covid-19[5]. Perlu dilakukan pengukuran secara berkala terkait pengetahuan dan sikap perawat untuk mengurangi tingkat stress perawat.

Rumah sakit memiliki tugas pokok untuk mengadakan upaya proses penyembuhan serta pemulihan yang diaplikasikan secara serasi, terpadu dan berkesinambungan dengan tujuan peningkatan kesehatan dan pencegahan serta melaksankan upaya rujukan dan upaya lain sesuai dengan kebutuhan [6]. Hasil studi pendahuluan menyebutkan jumlah pasien pada tanggal 4 Mei 2020 yang terkonfirmasi positif Covid19 dan dirawat di RSUP Dr. Kariadi sejumlah 91 pasien. Tercatat juga bahwa 25 pasien sembuh dari Covid-19 setelah di rawat [7].

Tingginya jumlah pasien yang terkonfirmasi positif Covid-19 dan dirawat di Rumah Sakit menjadikan tenaga kesehatan di lingkup tersebut lebih rentan terpapar virus corona. Data yang dihimpun hingga 17 April 2020 menunjukkan bahwa 57 pegawai di lingkup RSUP Dr. Kariadi Semarang positif terinfeksi virus corona. Komposisi pegawai yang terinfeksi virus corona tersebut terdiri dari dokter spesialis, perawat, fisioterapis dan tenaga lain seperti tenaga administrasi serta peserta pendidikan dokter spesialis.
Berdasarkan data-data awal tersebut, penulis memandang perlu dilakukan studi untuk mengkaji pengetahuan dan sikap petugas kesehatan mengenai Covid-19 dimana bertujuan membantu rumah sakit mempersiapkan program pendidikan apa yang dibutuhkan untuk mengurangi resiko pajananan Covid-19 terhadap tenaga kesehatan sehingga kualitas pelayanan rumah sakit dapat terjaga bahkan ditingkatkan.

\section{METODE}

Penelitian ini merupakan penelitian kuantitatif non eksperimental dengan rancangan deskriptif korelasi. Penelitian ini akan menggunakan pendekatan cross sectional dengan melakukan pengukuran secara bersamaan pada variabel pengetahuan perawat dan sikap perawat terkait Covid-19 di ruang Isolasi RSUP Dr. Kariadi Semarang.

Populasi dalam penelitian ini adalah perawat yang bekerja di ruang perawatan isolasi pasien Covid-19 RSUP Dr. Kariadi Semarang di bulan Juni 2020 sebanyak 101 perawat. Penelitian ini sampel diambil dengan teknik consecutive sampling dan didapatkan sampel sebanyak 81 responden. Tempat penelitian pada penelitian ini adalah di Ruang Isolasi RSUP Dr. Kariadi Semarang. Penelitian ini dilakukan dalam jangka waktu 4 bulan yakni bulan Juni September 2020.

Pengumpulan data dilakukan dengan cara menggunakan kusioner. Dalam penelitian ini terdiri dari kuesioner karakteristik demografi perawat, kuesioner pengetahuan perawat mengenai Covid-19 dan kuesioner sikap perawat terhadap Covid-19.

Sumber data dalam penelitian ini merupakan data primer, yaitu data yang diperoleh dari kuesioner yang diisi secara langsung oleh responden. Langkah-langkah yang dilakukan peneliti dalam pengumpulan data terbagi menjadi prosedur administratif dan prisedur teknis. 
Prosedur administratif dalam penelitian ini adalah: (1) Mengajukan permohonan ethical clearance kepada Komisi Etik RSUP Dr. Kariadi Semarang; (2) Mengajukan permohonan izin penelitian di bagian diklat RSUP Dr. Kariadi Semarang. (3) Mengajukan permohonan izin penelitian kepada Kepala Instalasi Rawat Intensif dan Kepala Instalasi Rajawali RSUP Dr. Kariadi Semarang. Proserdur teknisnya adalah: (1) Memilih responden berdasar kriteria inklusi; (2) Menjelaskan tujuan, manfaat, dan cara pengumpulan data kepada calon responden; (3) Memberikan lembar permohonan dan persetujuan untuk menjadi responden; (4) Mengumpulkan dan memeriksa kembali kelengkapan isian kuesioner dari responden; (5) Melakukan pengolahan dan analisis data.

Penelitian dilakukan setelah mendapatkan ijin persetujuan etik (ethical clearance) dariKEPK RSUP Dr. KariadiSemarang dengan nomor 569/EC/KEPK-RSDK/2020 tanggal 13 Juli 2020.Setelah surat laik etik diterima, peneliti memilah responden sesuai kriteria inklusi. Prosedur selanjutnya memberikan informed consent pada responden yang terpilih dalam riset. Riset diawali dengan menerangkan prosedur riset terlebih dulu. Prinsip etik lain juga diterapkan dalam penelitian ini seperti anonimity.

Penentuan tinggi/rendah pengetahuan dan baik/kurang baiknya sikap sama-sama menggunakan skor rerata yaitu masingmasing 30 dan 24. Peneliti melakukan uji silang/cross sectional untuk mengetahui adanya hubungan antara pengetahuan dan sikap perawat isolasi Covid-19 RSUP Dr. Kariadi Semarang.

\section{HASIL}

Data diambil pada bulan Juni-Juli dimana peningkatan jumlah kasus positif begitu pesat dengan jumlah responden adalah 81 partisipan yang memenuhi kriteria inklusi. Data yang disajikan adalah berupa karakteristik responden berupa usia, jenis kelamin, jenjang pendidikan, lama bekerja dan sumber informasi serta variabel penelitian berupa pengetahuan dan sikap perawat terkait covid-19. Berikut adalah sajian data hasil penelitian.

Tabel 1 menunjukan rata-rata pengetahuan $41,82 \pm 3,515$ dengan skor minimal 35 dan skor maksimal 48 serta rata-rata sikap adalah $35,39 \pm 2,890$ dengan skor minimal 30 dan skor maksimal 40 . Semua responden memiliki pengetahuan dan sikap yang baik. Ada perbedaan tingkat pengetahuan dan sikap pada masing-masing indikator. Masing-masing indikator usia memiliki selisih $\pm 0,725$, jenis kelamin memiliki selisih $\pm 0,760$, lama bekerja memiliki selisih $\pm 0,41$ dan sumber informasi memiliki selisih \pm 1,740.

Grafik scatter menunjukan adanya hubungan antara pengetahuan dian sikap perawat. Semakin diagonal garis linier maka semakin berhubungan kedua variabel tersebut, selain itu signifikansi menunjukan nilai $p=0,000$ dan kekuatan korelasi kuat dengan hubungan searah yang ditunjukan nilai correlation coefficient $+0,583$.

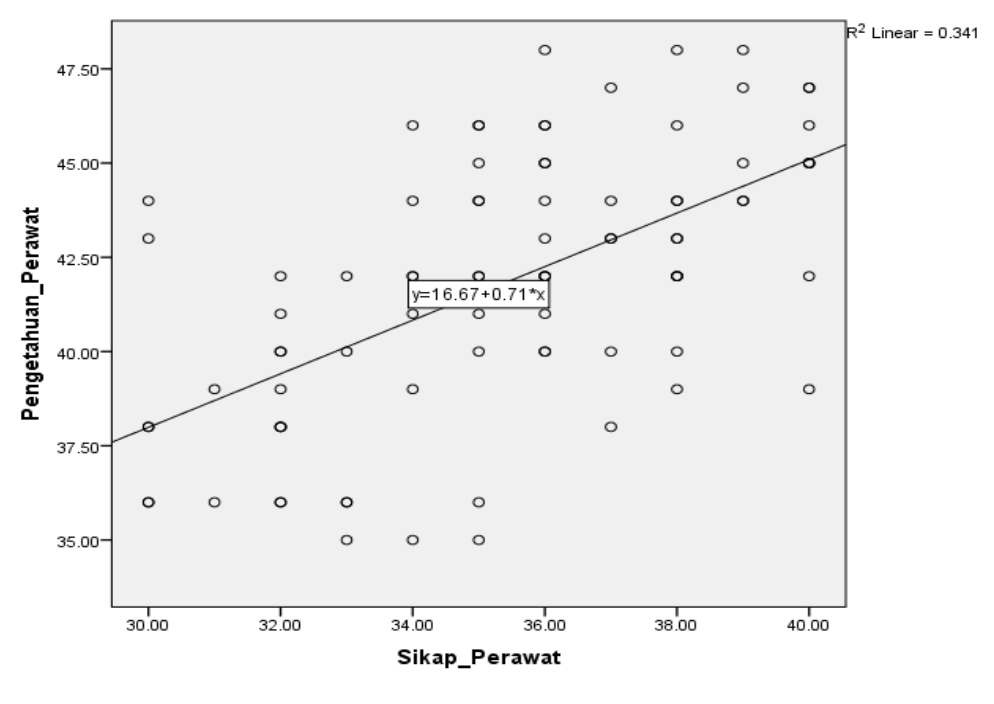

Gambar 1

Hubungan Pengetahuan Perawat dengan Sikap Perawat 
Tabel 1

Pengetahuan dan Sikap Perawat Isolasi Covid-19 RSUP Dr. Kariadi Semarang (n=81)

\begin{tabular}{|c|c|c|c|}
\hline Indikator & Pengetahuan & Sikap & $\mathrm{p}$ \\
\hline \multicolumn{4}{|l|}{ Usia } \\
\hline 17-24 Tahun & $41,50 \pm 3,694$ & $36,10 \pm 2,913$ & \multirow{14}{*}{$0.000^{*}$} \\
\hline 25-34 Tahun & $41,43 \pm 3,636$ & $35,21 \pm 2,802$ & \\
\hline 35-49 Tahun & $42,82 \pm 2,914$ & $35,47 \pm 3,019$ & \\
\hline \multicolumn{4}{|l|}{ Jenis Kelamin } \\
\hline Laki-laki & $40,60 \pm 3,322$ & $34,83 \pm 3,277$ & \\
\hline Perempuan & $42,50 \pm 3,435$ & $35,70 \pm 2,600$ & \\
\hline \multicolumn{4}{|l|}{ Pendidikan } \\
\hline DIII Keperawatan & $41,50 \pm 3,661$ & $35,18 \pm 2,840$ & \\
\hline S1 Ners & $42,26 \pm 3,238$ & $35,70 \pm 1,935$ & \\
\hline \multicolumn{3}{|l|}{ Lama Bekerja } & \\
\hline$<5$ Tahun & $41,52 \pm 3,657$ & $35,04 \pm 2,773$ & \\
\hline 5-10 Tahun & $41,93 \pm 3,454$ & $35,52 \pm 2,923$ & \\
\hline \multicolumn{3}{|l|}{ Sumber Informasi } & \\
\hline Televisi & $42,27 \pm 3,330$ & $34,88 \pm 3,107$ & \\
\hline Internet & $41,00 \pm 3,991$ & $35,48 \pm 2,607$ & \\
\hline $\begin{array}{l}\text { Website Rumah Sakit / } \\
\text { Pemerintah }\end{array}$ & $42,21 \pm 2,783$ & $36,21 \pm 2,667$ & \\
\hline
\end{tabular}

\section{PEMBAHASAN}

Penelitian menunjukan bahwa rata-rata pengetahuan dan sikap perawat dalam kategori baik. Terdapat faktor-faktor yang mempengaruhi pengetahuan yaitu pendidikan, informasi/media massa, pekerjaan, lingkungan, pengalaman, usia, sosial, budaya dan ekonomi[8]. Penelitian menunjukan semakin meningkatnya usia daya tangkap serta pola piker terhadap sesuatu objek akan meningkat sehingga dapat disimpulkan semakin bertambahnya usia maka pengetahuan akan semakin baik[8].

Semakin tinggi tingkat pendidikan seseorang maka semakin baik pula tingkat pengetahuannya., semakin tinggi pendidikan seseorang maka semakin mudah pula mereka menerima informasi dan makin banyak pula pengetahuan yang dimilikinya. Sebaliknya, seseorang yang mempunyai tingkat pendidikan yang rendah, akan terhambat perkembangan sikap seseorang tersebut terhadap suatu penerimaan, informasi dan nilai-nilai yang baru diperkenalkan[9]. Kemampuan dan pekembangan seseorang secara berkesinambungan dipengaruhi oleh tingkat pendidikan. Pendidikan dasar diberikan dengan tujuan sebagai dasar hidup dalam pengetahuan dan ketrampilan dasar kemudian dilanjutkan dengan pendidikan lanjutan[10]. Penelitian lain juga menunjukan adanya hubungan yang signifikan antara tingkat pendidikan dan pengetahuan kesehatan gigi dan mulut guru penjakses di Gianyar bali [11]. Penelitian tersebut didukung oleh penelitian lain yang menunjukan adanya hubungan yang signifikan antara tingkat pendidikan dengan pengetahuan dan perilaku perawat dalam melakukan vulva hygine [12].

Sikap seseorang adalah dibentuk dan dipelajari berdasarkan pengalaman dan latihan sepanjang perkembangan individu, bukan bawaan sejak lahir. Manusia tidak akan pernah bisa lepas untuk berinteraksi dengan orain lain karena pada dasarnya manusia adalah makhluk sosial. Hal tersebut merupakan faktor eksternal yang dapat mempengaruhi sikap manusia, akan tetapi terdapat pula faktor internal yang dapat mempengaruhi sikap seseorang seperti faktor fisiologis (lapar, haus dan sakit)[13]. Penelitian menyebutkan bahwa 
tingkat pendidikan perawat berpengaruh secara signifikan terhadap sikap caring perawat [14]. Penelitian tersebut didukung oleh penelitian dengan hasil adanya hubungan tingkat pendidikan dengan sikap perawat dalam melaksanakan perawatan luka [15].

Media massa memiliki peran yang besar dalam pengetahuan untuk memberikan informasi terhadap masyarakat termasuk pengetahuan kesehatan baik secara media cetak ataupun online. Media massa merupakan alat untuk terlaksananya sebuah proses komunikasi baik itu informasi, pesan maupun pengetahuan kepada tujuan sasaran[16]. Pendidikan non formal bisa berupa kursus, penyuluhan, iklan, leaflet, media massa dll[10]. Sebuah informasi akan menjadi pondasi kognitif terbentuknya pengetahuan terhadap informasi tersebut[17].

Lama bekerja juga mempengaruhi pengetahuan dan sikap. Semakin lama seseorang menekuni pekerjaannya maka akan semakin baik pengetahuan dan sikapnya terhadap pekerjaan tersebut [18]. Teori tersebut didukung oleh penelitian yang menyatakan adanya hubungan yang signifikan antara lama bekerja dengan pengetahuan tentang leukimia pada anak oleh petugas kesehatan [19]. Peneltian tersebut didukung kembali oleh penelitian yang menyebutkan pengetahuan ibu terhadap penanganan demam sangat baik pada ibu yang sudah berpengalaman dalam menangani demam pada anak [20]. Penelitian lain serupa juga menyebutkan lingkungan pekerjaan berperan bagi seseorang untuk memperoleh pengalaman dan pengetahuan baik secara langsung maupun tidak langsung. Pengalaman merupakan suatu cara untuk memperoleh kebenaran pengetahuan baik dari pengalaman diri sendiri maupun orang lain. Hal ini tersebut dilakukan dengan cara pengulangan kembali pengalaman yang diperoleh dalam memecahkan permasalahan yang dihadapi[9]. Pendidikan dapat mempengaruhi seseorang akan pola hidup terutama dalam memotivasi untuk sikap berperan serta dalam melakukan suatu perubahan. Pendidikan dapat menjadi pengalaman seseorang.

Kesimpulan penelitian ini menunjukkan adanya hubungan yang signifikan antara tingkat pengetahuan perawat tentang Covid-19 terhadap sikap perawat. Temuan studi ini menunjukkan bahwa semakin tinggi tingkat pengetahuan perawat tentang Covid-19 akan semakin meningkatkan sikap positf perawat tentang Covid-19. Pengetahuan secara umum diperoleh dari penginderaan melalui pancaindera manusia, yaitu indera penglihatan, pendengaran, penciuman, rasa dan raba. Sebagian besar pengetahuan manusia diperoleh melalui mata dan telinga. Sikap manusia merupakan kesiapan atau kesediaan untuk bertindak dan bukan pelaksanaan dari motif tertentu[21]. Pengetahuan seseorang tentang kesehatan merupakan salah satu aspek penting sebelum terjadinya perilaku kesehatan, sikap merupakan suatu bentuk kesiapan atau kesediaan untuk bertindak, dan bukan merupakan pelaksanaan motif tertentu [22]. Output sikap setiap individu akan menunjukan respon yang berbeda, ketika manusia menyukai suatu objek mereka akan cenderung mendekat, mencari tahu, dan bergabung, sebaliknya jika tidak suka atau tidak setuju maka akan menghindar atau menjauhi [17].

Semakin baik pengetahuan perawat maka akan semakin baik sikap yang dimiliki. Pengetahuan yang meningkat akan menentukan bagaimana seseorang mengambil sikap dan keputusan. Seseorang yang memiliki dasar/knowledge yang bagus tentu saja keputusan yang dihasilkanpun akan baik dan bijak. Tentu saja hal tersebut tidak $100 \%$ benar karena masih banyak faktor-faktor lain yang perlu dikaji sehingga diharapkan dilakukan penelitian ditempat yang berbeda lanjutan agar data yang dihasilkan semakin objektif. 


\section{SIMPULAN}

Adanya hubungan antara pengetahuan perawat terkait Covid-19 dan sikap perawat isolasi Covid-19. Semakin baik pengetahuan perawat maka akan semakin baik sikap yang dimiliki.

\section{UCAPAN TERIMAKASIH}

Terimakasih kepada responden yang telah bersedia menjadi bagian dari penelitian ini dan semua rekan sejawat di Instalasi Rawat Intensif yang telah berpartisipasi dalam penelitian ini.

\section{REFERENSI}

[1] Perhimpunan Dokter Paru Indonesia. Panduan Praktik Klinis: Pneumonia 2019-nCoV. Jakarta: PDPI; 2020.

[2] Abdullah A, C Allen. Knowledge, attitude and behaviours of Healthcare Workers in The Kingdom of Saudi Arabia to MERS Coronavirus and Other Emerging Infections Disease. Int J Env Res Public Heal 2016;13.

[3] Sameer A, Mohammad B, Mansour A, Abdulrahman A. Knowledge and Attitude of Dental Health Professionals about Middle East Respiratory Syndrome in Saudi Arabia. .J Int Soc Prev Community Dent 2018;137-144.

[4] Marwa M. Nurses' knowledge and Attitude about Covid-19 among elderly patients at Intensive Care Units: suggested education. Int J Adv Res Nurs 2020;3:14-21.

[5] Suphi, Aydin; Aydin B. COVID-19 Knowledge Level Research in Nurses. J Surg Res 3 2020;2:198-203.

[6] Rumah Sakit Umum Pusat dr. Kariadi Semarang. Profil: Profil Kami 2016.

[7] Provinsi Jawa Tengah DK. Sebaran Kasus COVID-19 Di Jawa Tengah. Tanggap Covid-19 $2020 . \quad$ https://corona.jatengprov.go.id/ (accessed April 20, 2020).

[8] Notoatmodjo S. Promosi Kesehatan dan Perilaku Kesehatan. Cetakan Pe. Jakarta: Rineka Cipta; 2012.

[9] Mubarak, W. I., Chayatin, N., Khoirul, I. R. S. Promosi Kesehatan Sebuah Pengantar Proses Belajar Mengajar dalam Pendidikan. Yogyakarta: Graha Ilmu; 2007.
[10] Tirtarahardja U, La Sulo. Pengantar Pendidikan. Jakarta: Rineka Cipta; 2005.

[11] Dharmawati IGAA, Wirata IN. Hubungan Tingkat Pendidikan, Umur, Dan Masa Kerja Dengan Tingkat Pengetahuan Kesehatan Gigi Dan Mulut Pada Guru Penjaskes Sd Di Kecamatan Tampak Siring Gianyar. J Kesehat Gigi 2016;4:1-5.

[12] Verawati, Wardani RS, Aggraini NN. Hubungan Tingkat Pendidikan Dan Pengetahuan Dengan Perilaku Perawatan Vulva Hygiene Pada Wanita Di Lapas Semarang Tahun 2014. J Kebidanan 2015;4:21-6.

[13] Sunaryo. Psikologi Untuk pendidikan. Jakarta: EGC; 2004

[14] Bella M. Hubungan Tingkat Pendidikan Perawat dengan Perilaku Caring Perawat di Rumah Sakit Umum Daerah Panembahan Senopati Bantul. UMY 2015;151:10-7.

[15] Noch L, Rompas S, Kallo V. Hubungan Tingkat Pendidikan Dan Sikap Dengan Pelaksanaan Prosedur Tetap Perawata Luka Di Ruang Perawatan Bedah Badan Rumah Sakit Daerah Kabupaten Banggai. J Keperawatan UNSRAT 2015;3:104834.

[16] Suhandjati. Pemahaman Islam dan Tantangan Keadilan Gender. Yogyakarta: Gama Meedia; 2005.

[17] Budiman, Riyanto A. Kapita selekta kuesioner : pengetahuan dan sikap dalam penelitian kesehatan. Jakarta: Salemba Medika; 2014.

[18] Fadli F, Safruddin S, Ahmad AS, Sumbara S, Baharuddin R. Faktor yang Mempengaruhi Kecemasan pada Tenaga Kesehatan Dalam Upaya Pencegahan Covid-19. J Pendidik Keperawatan Indones 2020;6:57-65. https://doi.org/10.17509/jpki.v6i1.24546.

[19] Sepang F, Gunawan S, Pateda V. Faktor-Faktor Yang Berhubungan Dengan Tingkat Pengetahuan Tentang Leukemia Anak Pada Petugas Kesehatan Puskesmas Manado. J eBiomedik 2013;1:743-7. https://doi.org/10.35790/ebm.1.1.2013.4629.

[20] Cahyaningrum ED\& ASS. Faktor-Faktor Yang Berhubungan Dengan Tingkat Pengetahuan Ibu Dalam Penanganan Demam Pada Anak Di Puskesmas I Kembaran Kabupaten Banyumas. J Publ Kebidanan 2018;9:1-13.

[21] Fitriani. S. Promosi Kesehatan. 1st ed. Jakarta: EGC; 2011.

[22] Notoatmodjo S. Metodologi Penelitian dalam Kesehatan 2011 